\title{
JOURNAL.RU
}

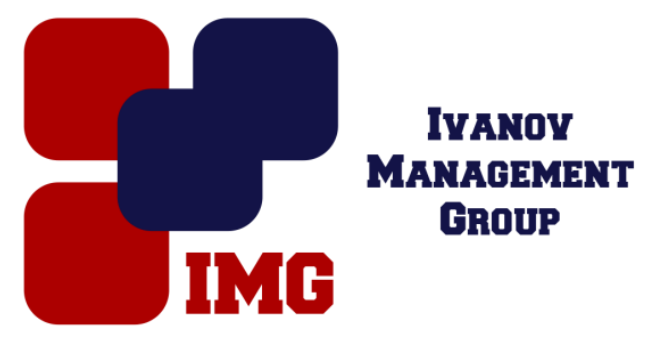

Образцов П.И. Орловский государственный университет имени И.С. Тургенева Орел, Россия

doi: 10.18411/1j-31-07-2017-04

idsp 000001:1j-31-07-2017-04

\section{Информационные технологии обучения в высшей школе: сущность и содержательная характеристика}

\begin{abstract}
Аннотация
В статье раскрываются подходы к современной интерпретации понятия «информационная технология обучения.

Ключевые слова: информационная технология обучения, высшая школа.

В связи с бурным развитием научно-технического прогресса, с появлением в вузах компьютерной и другой информационной техники, последние вполне объективно выделились в самостоятельное направление технологизации учебного процесса. Основным критерием, по которому можно отнести ту или иную технологию обучения к информационной является совокупность используемых преподавателем дидактических средств. Таким образом, следует иметь в виду, что информационная технология обучения является производной от технологии обучения, одним из ее частных случаев. Остановимся на этом более подробно, чтобы уточнить сущность и содержание данной дефиниции широко используемой для подготовки студентов в высшей школе.

Информационный поиск в научной и научно-методической литературе, посвященной проблемам информатизации профессионального образования, показал, что однозначного толкования понятия информационная технология обучения (computerized teaching technology) до сих пор не выработано. Приход в образовательные учреждения новых аппаратных и программных средств, наращивающих возможности компьютера, переход в разряд анахронизма понимания его как вычислителя, постепенно привели к вытеснению термина
\end{abstract}


«компьютерные технологии» понятием «информационные технологии». Последние характеризуются средой, в которой осуществляются: техническая среда (вид используемой техники для решения основных задач); программная среда (набор программных средств); предметная среда (содержание конкретной предметной области науки, техники, знания); технологическая (методическая) среда (инструкции, порядок пользования, оценка эффективности и др.).

Содержательный анализ определений данной дефиниции, наиболее часто встречающихся сегодня в педагогической литературе, позволил выделить два явно выраженных подхода к их трактовке. В рамках первого из них предлагается рассматривать информационную технологию обучения как дидактический процесс, организованный с использованием совокупности внедряемых (встраиваемых) в систему обучения принципиально новых средств и методов обработки данных (методов обучения), представляющих целенаправленное создание, передачу, хранение и отображение информационных продуктов (данных, знаний, идей) с наименьшими затратами и в соответствии с закономерностями познавательной деятельности студентов. В рамках второго речь идет о создании определенной технической среды обучения, в которой ключевое место занимают используемые информационные средства. Таким образом, в первом случае говорится о технологии как процессе обучения, а во втором случае об использовании в учебном процессе специфических программно-технических средств.

Анализ научной и научно-методической литературы по проблеме информатизации профессионального образования позволяет утверждать, что превалирующим на сегодняшний день является второй подход, который условно можно называть «технократическим». Об этом убедительно свидетельствует тот факт, что все руководящие документы - программы, концепции, инструкции и образовательные стандарты, касающиеся информатизации образования, подготовленные и опубликованные Министерством образования и науки России, выдержаны в данном ключе. Это, на наш взгляд, объясняется следующим образом. Бурное развитие в 80-90 г.г. прошлого века компьютерной техники и программного обеспечения привело к необходимости активного их внедрения в образовательный процесс вузов. Однако освоение, а тем белее прикладное использование их в педагогической практике оказалось в это время под силу далеко не всем представителям педагогической интеллигенции. Лидерство в этом вопросе по праву захватили представители технических наук, имеющие соответствующую подготовку и 
квалификацию. Представители гуманитарных наук, предметная область которых оказалась слабо структурированной, плохо поддающейся программированию, а значит и информатизации в широком понимании ее смысла, явно отстали. К сожалению, приходится констатировать факт, что эти тенденции продолжают сохраняться и до сегодняшнего дня. Все это привело к тому, что разработка дидактико-методологических и теоретико-методических основ информатизации образования сейчас явно не поспевает за развитием научнотехнического прогресса в области информатики.

Являясь сторонниками первого из указанных подходов, в то же время, не отрицаем право на существование второго. Однако считаем, что рассмотрение информационной технологии обучения только с точки зрения внедрения компьютерных и других информационных средств в учебный процесс значительно сужает рамки понимания самой сущности информатизации обучения. В этом случае целесообразно говорить только об автоматизации тех или иных сторон процесса обучения, о переносе информации с бумажных носителей в компьютерный вариант, о расширяющихся возможностях визуализации представляемой студентам учебной информации и т.д.

С точки зрения дидактики, можно вести речь об информационной технологии обучения только в том случае, если она: удовлетворяет основным признакам технологизации обучения (предварительное проектирование, диагностическое целеобразование, системная целостность, воспроизводимость и т. д.); решает задачи, которые ранее в учебном процессе не были теоретически или практически решены; в качестве средства сбора, обработки, хранения и представления учебной информации обучающемуся выступает целостный комплекс компьютерных и других информационных средств, выбор или разработка которых обусловлены целями и дидактическими задачами, решаемыми педагогом.

Таким образом, под информационной технологией обучения предлагается понимать дидактический процесс с применением целостного комплекса компьютерных и других средств обработки информации, позволяющий на системной основе организовать оптимальное взаимодействие между преподавателем и студентами с целью достижения гарантированного педагогического результата. 
1. Виленский М.Я., Образцов П.И., Уман А.И. Технологии профессионально-ориентированного обучения в высшей школе: Учебное пособие / Под ред. В.А. Сластенина. Педагогическое общество России, 2002. - 192 с.

2. Виленский М.Я., Образцов П.И., Уман А.И. Технология профессионально-ориентированного обучения в высшей школе: Учебное пособие. Издание третье / Под ред. В.А. Сластенина. Орел: ГОУ ВПО «ОГУ», 2008. - 270 с.

3. Образцов П.И. Дидактические основы проектирования и конструирования профессионально-ориентированных технологий в вузе. // Педагогическое образование и наука. 2005. - № 3. - С. 70-74.

4. Образцов П.И. Основы профессиональной дидактики. Учебное пособие. - - Орел: «Горизонт», 2013. - $330 \mathrm{c.}$

5. Образцов П.И. Основы профессиональной дидактики: учебное пособие. - М.: $\quad$ Вузовский учебник: ИНФРА-М, 2015. - 288 с.

6. Образцов П.И., Козачок А.И. Формирование компетентности у военных специалистов в вузе средствами профессионально-ориентированной технологии обучения: Академия ФСО России. - Орел, 2005. - 173 с.: ил. - Библиогр.: 191 назв. - Деп. в ВИНИТИ 15.06.05. № 846B2005. 